\title{
Growth, nutrient utilization, body composition, hematology and histopathology of the liver of Clarias gariepinus fed cooked sunflower based diets
}

\author{
Wasiu Adeyemi Jimoh \\ Department of Aquaculture and Fisheries, Faculty of Agriculture, University of Ilorin, PMB 1515, Ilorin, Nigeria \\ https://orcid.org/0000-0003-0174-301X \\ jimoh.wa@unilorin.edu.ng \\ Received date: 27.12 .2019 \\ Accepted date: 09.06 .2020 \\ How to cite this paper: \\ Jimoh, W.A. (2020). Growth, nutrient utilization, body composition, hematology and histopathology of the liver of Clarias gariepinus fed cooked sunflower \\ based diets. Ege Journal of Fisheries and Aquatic Sciences, 37(4), 343-351. DOI: 10.12714/egejfas.37.4.04
}

Abstract: This study investigated the use of cooked sunflower seed meal as soybean meal replacer in Clarias gariepinus diet in a 56-day feeding trial using growth performance, nutrient utilization, body composition, digestibility, hematology and liver histology as indices of assessment. Sunflower seed meal was cooked for 10, 20 and 30 minutes. Each of the differently cooked sunflower seed meal replaced soybean meal portion of control diet at 15,30 and $45 \%$ to produce nine $40 \%$ crude protein, $18 \mathrm{~kJ} / \mathrm{g}$ test diets. A diet without sunflower meal served as the control. Triplicate groups of fish in 70 -litre capacity aerated rectangular plastic tanks were alloted to each dietary treatment at a stocking rate of 15 fingerlings ( $3.72 \pm 0.22 \mathrm{~g}$ average weight) per tank in a completely randomized design. Fish were fed to satiation. Data obtained from the experiment were subjected to statistical analysis. The results of the experiment revealed that up to $30 \%$ replacement level of 10 - and 20 -minutes cooked sunflower produced a statistically similar results with soybean-based control diets.

Keywords: sunflower, Clarias gariepinus, haematology, histopathology, digestibility

\section{INTRODUCTION}

The trend of growth in aquaculture production witnessed in the recent years all over the world (Troell et al., 2014) calls for the need to develop economical feed that will support the growth of fish and sustainable aquaculture production (Azaza et al., 2009). Soybean has been a conventional protein source feed ingredient for aquaculture species but its competitive use among other livestock users and even human being is on the rise and this could be a threat to the sustainability of aquaculture production (Azaza et al., 2009; Tacon and Metian, 2008). A lot of researchers have ventured into prospecting the economically viable and nutritionally comparable plant protein source to ease the problem of high cost of conventional protein feedstuffs and their availability question in fish feed manufacture (Hassaan et al., 2017; Hassaan et al., 2015; Jimoh et al., 2013a; Jimoh and Aroyehun, 2011; Jimoh et al., 2014b; Jimoh et al., 2013b; Kumar et al., 2010; Saha and Ghosh, 2013). Sunflower seedmeal has been identified as a good source of especially sulphur-containing amino acids (Gohl, 1991). More so, like all other unconventional protein source, it is a low-cost plant protein source when compared to soybean meal (Hassaan et al., 2015; Köprücü and Sertel, 2012) and readily available in the market (Lozano et al., 2007). As a result of its good nutrient profile, research directions have been made on its use in fish feed. Sunflower seedmeal has been included in the diet Oreochromis mossambicus (Jackson et al., 1982); Onchorhynchus mykiss (Sanz et al., 1994; Tacon et al., 1984); Oreochromis niloticus (Sintayehu et al., 1996); Onchorhynchus mykiss (Stickney et al., 1996); Anguilla
Anguilla (Garcia-Gallego et al., 1998); Tilapia rendalli (OlveraNovoa et al., 2002); Salmo salar (Gill et al., 2006); Sparus aurata (Lozano et al., 2007); Acanthopagrus schlegelii (Hassaan et al., 2018). Work on inclusion of sunflower seed meal in the diet of Clarias gariepinus were Akintayo et al. (2008) and Fagbenro et al. (2010). However, a major setback to the use of plant protein sources lie in their deficiency in some essential amino acids primarily lysine, higher fibre content, the presence of anti-nutritional factors (Alarcón et al., 1999; Francis et al., 2001; Gaylord et al., 2004; Hertrampf and Piedad-Pascual, 2012).

Processing of plant protein sources is necessary in order to improve their nutritive value (Soltan, 2005). It leads to little or no antinutrient in plant protein sources thereby increase their utilization. Adeparusi and Jimoh (2002) reported that thermal processing of plant protein sources and their inclusion level significantly affect their digestibility not only in fish but also in other farm animals. Paucity of information exists on the use of sunflower in Clarias gariepinus diet. Akintayo et al. (2008) fed toasted sunflower meal to Clarias gariepinus while Fagbenro et al. (2010) included unprocessed sunflower seedmeal in Clarias gariepinus diet. An attempt is therefore being made in this study to investigate the inclusions of differently cooked sunflower seedmeal on the nutrient utilization, growth performance, digestibility, body composition, hematology and histopathology of the liver of Clarias gariepinus. 


\section{MATERIALS AND METHODS}

\section{Feed ingredients' processing and diet preparation}

Three batches of sunflower seed were put in boiling water $\left(100^{\circ} \mathrm{C}\right)$ for 10,20 and 30 minutes to serve as processing time interval. The seedmeal were dried, ground, and locally made screw press was used to mechanically defat the sample The three samples were designated as C10, C20 and C30 respectively according to their time of processing. Nine isonitrogenous (30\% crude protein) and isocaloric diet having fishmeal, soybean meal, sunflower meal, cassava flour, fish and vegetable oil (1:1) and vitamin - mineral premix as the ingredients. Each batch of sunflower were included at 15, 30 and $45 \%$ replacement level with soybean meal (Table 1) following the recommendation of Hertrampf and PiedadPascual (2012) that 20\% sunflower meal should be included in the omnivorous species. The feedstuff that has been pulverized with hot water added to aid binding was fed into a Hobart - 200T pelleting and mixing machine to produce pellets which were sun -dried $\left(30-32^{\circ} \mathrm{C}\right)$ then kept frozen in a refrigerator. Proximate composition of the diets prepared were carried out using the methods of AOAC (1990). physiological value of $5.61 \mathrm{Kcal} / \mathrm{g}$ protein, $9.50 \mathrm{Kcal} / \mathrm{g}$ lipid and $4.11 \mathrm{Kcal} / \mathrm{g}$ carbohydrate (Tacon, 1995) was used in determining the gross energy content of samples. The method of Spackman et al. (1958) was followed in amino acid analysis of differentlyprocessed sunflower seed meals using the ion exchange chromatography (IEC). The amino acid analysis was carried out in the Department of Zoology, University of Jos, Nigeria using Automatic Technicon Sequential Multi-sample Amino Acid Analyzer (Model No 0209, Technicon, Ireland).

Table 1. Proximate composition and essential amino acid profile of differently processed sunflower seed meal

\begin{tabular}{lccc}
\hline \multirow{2}{*}{ Proximate } & \multicolumn{3}{c}{ Processed Sunflower } \\
\cline { 2 - 4 } & C10 & C20 & C30 \\
\hline Moisture & 9.1 & 8.97 & 9.28 \\
Crude Protein & 40.39 & 38.36 & 35.83 \\
Crude Fibre & 11.90 & 12.83 & 12.58 \\
Crude Lipid & 5.38 & 6.22 & 5.41 \\
Ash & 11.28 & 10.38 & 12.28 \\
NFE & 22.02 & 22.02 & 24.62 \\
Amino Acid & & & \\
Lysine & 3.68 & 3.36 & 3.20 \\
Histidine & 2.00 & 3.56 & 2.92 \\
Arginine & 8.97 & 8.95 & 9.04 \\
Threonine & 3.13 & 3.34 & 3.41 \\
Valine & 3.97 & 4.03 & 4.07 \\
Methionine & 1.03 & 1.40 & 1.79 \\
Isoleucine & 2.91 & 3.22 & 4.95 \\
Leucine & 3.72 & 5.92 & 6.29 \\
Phenylalanine & 5.71 & 5.04 & 5.07 \\
\hline
\end{tabular}

\section{Experimental system and fish}

Fingerlings of Clarias gariepinus $(<5 \mathrm{~g})$ were obtained from Ondo state Government Fish Farm, Alagbaka, Akure, Nigeria and transported life to the laboratory of the Department of Fisheries and Aquaculture inside aerated polythene bags. The fish was acclimated in glass tanks on commercial pelleted diet for seven days. Fifteen fingerlings were stocked into each tank randomly with three replications per treatment. Experimental diet was allotted randomly to the tanks and each group of fish was fed to apparent satiation two times in a day at 9:00-10:00 hrs and 16:00-17:00 hours for 56 days. Fish was removed from each tank every 14 days and batch-weighed with the weight in each dietary group recorded accordingly. Siphoning during the first 3 weeks of the experiment served to collect faecal samples. The faecal samples were oven - dried at $45^{\circ} \mathrm{C}$ and was analyzed for its proximate composition. Daily mortality was monitored and recorded. At the beginning of the feeding trial and at the end, composite whole fish was sacrificed for carcass analysis of its crude protein, crude Ash fibre, and lipid. Dissolved Oxygen and water temperature were monitored three times in each week using a combined digital YSI Do Meter (YSI, Model 57) electronic $\mathrm{pH}$ meter (Metter Toledo, Model 320) was used in monitoring $\mathrm{pH}$.

\section{Acid insoluble ash (AIA) analysis}

The AIA was calculated based on the procedures explained in Adeparusi and Jimoh (2002). AIA in faeces and feed was gotten by adding $25 \mathrm{ml}$ of $10 \% \mathrm{HCl}$ to the ash content that has been previously weighed with a water glass serving as cover. The resulting mixture was boiled gently over a low flame for 5 minutes after which it was filtered using ashless filter and washed with hot distilled water, the residue from the filter was returned into the crucible and then ignited until it is carbon - free and it was weighed.

$$
\% \text { AIA }=\frac{\text { weight of AIA }}{\text { weight of ash }} \times 100
$$

\section{Digestibility Coefficient}

The value obtained for AIA in different faecal samples and diets were used as indicator in the calculation of digestibility coefficient as described in Jimoh et al. (2014a); Jimoh et al. (2010).

Organic Matter Digestibility (AOMD) was calculated as follow

$\%$ AOMD $=100-\left[100 \frac{(\% \text { AIA in Feed })}{((\% \text { AIA in Faeces })}\right]$

$\%$ Digestibility $=100-\left[100 \frac{(\% \text { AIA in Feed })}{((\% \text { AIA in Faeces })} \times \frac{(\% \text { Nutrients in Faeces })}{(\% \text { Nutrients in Feed })}\right]$ 
Table 2. Gross, proximate composition ( $\mathrm{g} / 100 \mathrm{~g}$ dry matter), acid insoluble ash and energy content of experimental diets at varying replacement levels of differently cooked sunflower seedmeals

\begin{tabular}{|c|c|c|c|c|c|c|c|c|c|c|}
\hline & CTR & CSF115 & CSF130 & CSF145 & CSF215 & CSF230 & CSF245 & CSF315 & CSF330 & CSF345 \\
\hline Fishmeal & 27.24 & 27.24 & 27.24 & 27.24 & 27.24 & 27.24 & 27.24 & 27.24 & 27.24 & 27.24 \\
\hline Soybean Meal & 46.71 & 39.71 & 32.70 & 25.70 & 39.71 & 32.70 & 25.70 & 39.71 & 32.70 & 25.70 \\
\hline $\begin{array}{l}\text { Cooked } \\
\text { Sunflower }\end{array}$ & - & 7.62 & 15.24 & 22.87 & 7.92 & 15.84 & 23.75 & 8.34 & 16.68 & 25.01 \\
\hline Corn Meal & 11.25 & 11.25 & 11.25 & 11.25 & 11.25 & 11.25 & 11.25 & 11.25 & 11.25 & 11.25 \\
\hline Fish Oil & 5.09 & 5.09 & 5.09 & 5.09 & 5.09 & 5.09 & 5.09 & 5.09 & 5.09 & 5.09 \\
\hline \multicolumn{11}{|l|}{ Premix } \\
\hline Starch & 4.71 & 4.09 & 3.48 & 2.85 & 3.79 & 2.88 & 1.97 & 3.37 & 2.04 & 0.71 \\
\hline Total & 100 & 100 & 100 & 100 & 100 & 100 & 100 & 100 & 100 & 100 \\
\hline \multicolumn{11}{|c|}{ Proximate Composition } \\
\hline Moisture & $9.72 \pm 0.48$ & $9.28 \pm 0.10$ & $9.31 \pm 0.04$ & $9.77 \pm 0.46$ & $9.28 \pm 0.03$ & $9.29 \pm 0.03$ & $9.27 \pm 0.04$ & $9.38 \pm 0.03$ & $9.25 \pm 0.05$ & $9.36 \pm 0.06$ \\
\hline Crude Protein & $40.19 \pm 0.08$ & $40.30 \pm 0.08$ & $40.29 \pm 0.07$ & $40.27 \pm 0.11$ & $40.22 \pm 0.16$ & $40.29 \pm 0.09$ & $40.27 \pm 0.04$ & $40.24 \pm 0.07$ & $40.28 \pm 0.07$ & $40.27 \pm 0.01$ \\
\hline Crude Lipid & $12.16 \pm 0.02$ & $12.14 \pm 0.03$ & $12.13 \pm 0.05$ & $12.14 \pm 0.03$ & $12.15 \pm 0.05$ & $12.10 \pm 0.03$ & $12.17 \pm 0.05$ & $12.17 \pm 0.06$ & $12.17 \pm 0.06$ & $12.12 \pm 0.04$ \\
\hline Crude fibre & $9.72 \pm 0.04 \mathrm{a}$ & $9.72 \pm 0.15^{a}$ & $9.69 \pm 0.16^{a}$ & $9.78 \pm 0.10^{a}$ & $9.71 \pm 0.17 \mathrm{a}$ & $9.70 \pm 0.13^{a}$ & $9.58 \pm 0.14 \mathrm{ab}$ & $9.56 \pm 0.23 \mathrm{ab}$ & $9.36 \pm 0.09 b$ & $9.34 \pm 0.08^{b}$ \\
\hline Ash & $5.87 \pm 0.05$ & $5.84 \pm 0.12$ & $6.00 \pm 0.14$ & $5.60 \pm 0.55$ & $5.86 \pm 0.20$ & $5.99 \pm 0.73$ & $5.85 \pm 0.45$ & $5.71 \pm 0.42$ & $5.77 \pm 0.49$ & $5.79 \pm 0.47$ \\
\hline NFE & $22.33 \pm 0.51^{b}$ & $22.72 \pm 0.05^{a}$ & $22.58 \pm 0.22^{\mathrm{a}}$ & $21.00 \pm 2.17^{b}$ & $22.78 \pm 0.15^{a}$ & $22.62 \pm 0.82^{a}$ & $22.85 \pm 0.50^{a}$ & $22.95 \pm 0.21 \mathrm{a}$ & $23.17 \pm 0.40^{a}$ & $23.11 \pm 0.58^{a}$ \\
\hline AIA & $0.75 \pm 0.05$ & $0.80 \pm 0.02$ & $0.77 \pm 0.04$ & $0.78 \pm 0.05$ & $0.78 \pm 0.07$ & $0.77 \pm 0.03$ & $0.77 \pm 0.04$ & $0.82 \pm 0.07$ & $0.82 \pm 0.07$ & $0.79 \pm 0.07$ \\
\hline Energy $(\mathrm{KJ} / \mathrm{g})$ & $18.08 \pm 2.05^{\mathrm{ab}}$ & $18.17 \pm 0.48^{\mathrm{a}}$ & $18.13 \pm 1.13^{a}$ & $18.00 \pm 1.26^{b}$ & $18.16 \pm 1.83^{a}$ & $18.13 \pm 3.40^{\mathrm{a}}$ & $18.19 \pm 2.31^{\mathrm{a}}$ & $18.20 \pm 1.15^{\mathrm{a}}$ & $18.25 \pm 2.22^{\mathrm{a}}$ & $18.22 \pm 2.02^{\mathrm{a}}$ \\
\hline
\end{tabular}

Row means with different superscripts are significantly different $(\mathrm{p}<0.05)$ from each other

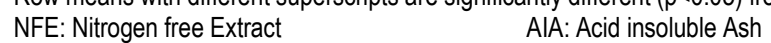

* Specification: each kg contains: Vitamin A , 4,000,000IU; Vitamin B, 800,000IU; Vitamin E, 16,000mg, Vitamin K3, 800mg; Vitamin B, 600mg; Vitamin B2, 2,000mg; Vitamin B6, 1,600mg, Vitamin B12,8mg; Niacin,16,000mg; Caplan, 4,000mg; Folic Acid, 400mg; Biotin, 40mg; Antioxidant 40,000mg; Chlorine chloride, 120,000mg; Manganese, 32,000mg; Iron 16,000mg; Zinc, 24,000mg; Copper 32,000mg; lodine 320mg; Cobalt,120mg; Selenium, 800mg manufactured by DSM Nutritional products Europe Limited, Basle, Switzerland

\section{Diet Performance Evaluation}

Growth performance and nutrient utilization of fish was determined following the methods described in Jimoh et al., (2019) for weight gain, feed conversion ratio, (FCR), Survival $(\%)$, protein efficiency ratio (PER), specific growth rate (SGR $\% /$ day), and, net protein utilization (NPU) responses was calculated as

Weight Gain $(\%)=\frac{\text { Final weight }- \text { Initial Weight }}{\text { Initial weight }} \times 100$

SGR (\%/day)

$=\frac{\ln (\text { final bodyweight })-\ln (\text { initial body weight })}{\text { Time (in days) }} \times 100$

$F C R=\frac{\text { dry weight of feed fed }}{\text { Fish weight Gain }}$

PER $=\frac{\text { Fish weight gain }}{\text { Protein Fed }}$

$N P U=\frac{\text { Net protein in Carcass }}{\text { Protein Fed }}$

\section{Hematological examination of the fish}

The blood of fish that has been previously euthanized in clove oil $(100 \mathrm{ml} / \mathrm{l})$ was obtained using heparinized syringe into a EDTA smeared sampling bottle. The procedure of Svobodova et al. (1991) was followed in the blood analysis.

\section{Histological examination of test organ}

At the end of the experiment, three fish per treatment was sampled for histological analysis; the test organisms that have been euthanized were cut open to excise the liver. After which the excised livers were fixed in $10 \%$ formalin and dehydrated in graded levels of $50 \%, 70 \%, 90 \%$ and $100 \%$ alcohol for 3 days, with the use of a rotatory microtome and staining with Harris haematoxyllin-eosin (H\&E) stain for ten minutes (Bancroft and Cook, 1994). The stained slide was observed under a light microscope and snapped using an Olympus $\mathrm{BH} 2$ microscope fitted with photographic attachment (Olympus C35 AD4), a camera (Olympus C40 AB-4) and an automatic light exposure unit (Olympus PM CS5P).

\section{Statistical analysis}

All data were expressed as mean \pm standard deviation and were analyzed using one-way analysis of variance (ANOVA) test using SPSS 17.0 version. Duncan's multiple range test (Zar, 1996) was used to separate the treatment means where ANOVA revealed significant difference $(P<0.05)$,

\section{RESULTS}

\section{Whole body composition}

The whole-body composition of fish at the beginning and at the end of the experiment is presented in Table 3. Significant variations $(P<0.05)$ existed between the final and initial body composition of fish used during the experiments with respect to proximate analysis. Carcass crude protein reduced with increase in cooking time and inclusion level. No significant variations $(p>0.05)$ was observed in the carcass protein of fish fed CTR, CSF115, CSF130, CSF215, CSF315 while the lowest value was recorded for fish fed CSF345. 
Table 3. Proximate composition of carcass of Clarias gariepinus fed varying levels varying replacement levels of cooked samples of sunflower seedmeal-based diets

\begin{tabular}{|c|c|c|c|c|c|c|c|c|c|c|c|}
\hline & \multirow{2}{*}{ Initial } & \multicolumn{10}{|c|}{ Experimental Diets } \\
\hline & & CTR & CSF115 & CSF130 & CSF145 & CSF215 & CSF230 & CSF245 & CSF315 & CSF330 & CSF345 \\
\hline Moisture & $76.62 \pm 0.14^{a}$ & $72.44 \pm 0.28 \mathrm{e}$ & $72.51 \pm 0.19 \mathrm{de}$ & $72.60 \pm 0.25$ cde & $72.76 \pm 0.09 \mathrm{~cd}$ & $72.56 \pm 0.21$ cde & $72.62 \pm 0.19$ cde & $72.72 \pm 0.02^{\text {cde }}$ & $72.62 \pm 0.03$ cde & $72.86 \pm 0.01^{a b}$ & $73.10 \pm 0.04^{b}$ \\
\hline C. Protein & $15.17 \pm 0.05^{e}$ & $17.83 \pm 0.12^{\mathrm{a}}$ & $17.72 \pm 0.14^{\mathrm{ab}}$ & $17.68 \pm 0.19 \mathrm{abc}$ & $17.58 \pm 0.09 \mathrm{bc}$ & $17.74 \pm 0.07 \mathrm{ab}$ & $17.58 \pm 0.05^{b c}$ & $17.51 \pm 0.05^{c}$ & $17.71 \pm 0.08^{\mathrm{ab}}$ & $17.53 \pm 0.06^{c}$ & $17.32 \pm 0.04^{d}$ \\
\hline .C. Lipid & $5.28 \pm 0.04^{f}$ & $6.39 \pm 0.03^{a}$ & $6.37 \pm 0.02^{\mathrm{ab}}$ & $6.35 \pm 0.03 \mathrm{abc}$ & $6.30 \pm 0.03^{\mathrm{de}}$ & $6.37 \pm 0.02^{\mathrm{ab}}$ & $6.35 \pm 0.02^{\mathrm{abc}}$ & $6.33 \pm 0.01 \mathrm{bcd}$ & $6.35 \pm 0.02^{\mathrm{abc}}$ & $6.32 \pm 0.01$ de & $6.29 \pm 0.02 \mathrm{e}$ \\
\hline Ash & $2.93 \pm 0.07 \mathrm{~g}$ & $3.53 \pm 0.04^{a}$ & $3.49 \pm 0.04 \mathrm{ab}$ & $3.44 \pm 0.03^{b c}$ & $3.36 \pm 0.02^{\mathrm{def}}$ & $3.45 \pm 0.05 b c$ & $3.43 \pm 0.03^{\mathrm{bcd}}$ & $3.38 \pm 0.03$ cde & $3.43 \pm 0.04$ cde & $3.34 \pm 0.06^{\mathrm{ef}}$ & $3.29 \pm 0.03^{f}$ \\
\hline
\end{tabular}

Row means with different superscripts are significantly different $(p<0.05)$ C. Crude

Table 4. Growth performance and nutrients utilisation of Clarias gariepinus fed cooked sunflower meal-based diets

\begin{tabular}{|c|c|c|c|c|c|c|c|c|c|c|}
\hline \multirow{2}{*}{ Parameters } & \multicolumn{10}{|c|}{ Experimental Diets } \\
\hline & CTR & CSF115 & CSF130 & CSF145 & CSF215 & CSF230 & CSF245 & CSF315 & CSF330 & CSF345 \\
\hline Ini. Weight & $3.45 \pm 0.05^{a}$ & $3.69 \pm 0.32^{a}$ & $3.36 \pm 0.52^{a}$ & $3.92 \pm 0.37^{a}$ & $3.80 \pm 0.20^{a}$ & $3.45 \pm 0.29 a$ & $4.02 \pm 0.06^{a}$ & $4.00 \pm 0.31^{a}$ & $3.77 \pm 0.49 \mathrm{a}$ & $.78 \pm 0.55^{a}$ \\
\hline Fin.Weight & $12.43 \pm 0.08 \mathrm{ab}$ & $12.32 \pm 0.14 \mathrm{abc}$ & $11.87 \pm 0.49 \mathrm{abcd}$ & $11.51 \pm 0.58 \mathrm{~cd}$ & $12.66 \pm 0.59 \mathrm{a}$ & $11.62 \pm 0.52^{\mathrm{bcd}}$ & $9.51 \pm 0.52^{f}$ & $11.85 \pm 0.60^{\mathrm{abcd}}$ & $11.26 \pm 0.42^{\mathrm{de}}$ & $10.53 \pm 0.30 \mathrm{e}$ \\
\hline 1M W Gain & $8.98 \pm$ & $8.63 \pm$ & $8.51 \pm 0.62^{\mathrm{abc}}$ & $7.59 \pm$ & $8.86 \pm 0.69 a$ & $8.18 \pm 0.80^{a b c d}$ & 5.48 & $7.85 \pm$ & $7.49 \pm$ & $6.75 \pm 0.26 \mathrm{e}$ \\
\hline 2\% W.Gain & $259.94 \pm 5.57^{a}$ & $235.45 \pm 25.73^{\mathrm{ab}}$ & $258.88 \pm 55.82^{a}$ & $194.36 \pm 13.54 b$ & $233.80 \pm 27.32^{2 \mathrm{~b}}$ & $239.42 \pm 42.07$ ab & $136 \pm 6.17 \mathrm{c}$ & $196.62 \pm 10.46^{b}$ & 202.39 & 191.84 \\
\hline${ }^{3} S G R$ & $2.29 \pm 0.03^{a}$ & $2.16 \pm 0.14^{a b c}$ & $2.27 \pm 0.27 \mathrm{a}$ & $1.93 \pm 0.80 c$ & $2.15 \pm 0.15 \mathrm{abc}$ & $2.17 \pm 0.22^{\mathrm{abc}}$ & $1.53 \pm 0.13^{d}$ & $1.94 \pm 0.06^{b c}$ & $1.97 \pm 0.25 \mathrm{abc}$ & $1.84 \pm 0.22^{c}$ \\
\hline 4FCR & $1.21 \pm 0.02^{d}$ & $1.22 \pm 0.02^{\mathrm{cd}}$ & $1.23 \pm 0.02^{\mathrm{bcd}}$ & $1.25 \pm 0.04 \mathrm{abc}$ & $1.22 \pm 0.02^{\mathrm{cd}}$ & $1.24 \pm 0.01 \mathrm{bcd}$ & $1.28 \pm 0.03^{a}$ & $1.24 \pm 0.02^{\mathrm{bcd}}$ & $1.24 \pm 0.02^{\mathrm{bcd}}$ & $1.27 \pm 0.04 \mathrm{ab}$ \\
\hline 5PER & $2.07 \pm 0.04^{a}$ & $2.05 \pm 0.03^{a b}$ & $2.03 \pm 0.04 \mathrm{abc}$ & $1.97 \pm 0.06^{\text {bcd }}$ & $2.05 \pm 0.03^{\mathrm{ab}}$ & $2.02 \pm 0.02^{\mathrm{abc}}$ & $1.94 \pm 0.04 \mathrm{bc}$ & $2.02 \pm 0.04$ abc & $2.01 \pm 0.04 \mathrm{abcd}$ & $1.97 \pm 0.06^{c d}$ \\
\hline${ }^{6 N P U}$ & $61.39 \pm 2.23^{b}$ & $60.53 \pm 4.49 \mathrm{~b}$ & $60.04 \pm 5.66^{b}$ & $63.39 \pm 5.21 \mathrm{~b}$ & $59.47 \pm 5.08^{b}$ & $59.77 \pm 6.60^{b}$ & $83.33 \pm 8.92^{a}$ & $65.25 \pm 0.54 b$ & $63.91 \pm 8.78^{b}$ & $62.64 \pm 2.75^{b}$ \\
\hline $7 \%$ Survival & $97.78 \pm 3.85^{\mathrm{ab}}$ & $97.78 \pm 3.85^{\mathrm{ab}}$ & $86.67 \pm 3.34^{\mathrm{ab}}$ & $82.22 \pm 3.85^{a}$ & $88.89 \pm 3.88 \mathrm{ab}$ & $97.78 \pm 3.85^{\mathrm{ab}}$ & $91.11 \pm 1.18^{\mathrm{ab}}$ & $91.11 \pm 3.85^{\mathrm{ab}}$ & $86.67 \pm 3.35^{\mathrm{ab}}$ & $86.67 \pm 3.84$ ab \\
\hline
\end{tabular}

Row means with different superscripts are significantly different $(p<0.05)$.

${ }^{1}$ Mean weight gain= final mean weight -initial mean weight $\quad 2$ Percentage weight gain= [final weight-initial weight /initial weight] $X 100$

${ }^{3}$ Specific growth rate= [In final weight-In initial weight] X $100 \quad 4$ Feed conversion ratio=dry weight of feed fed $/$ Weight gain $(\mathrm{g})$

${ }^{5}$ Protein efficiency ratio=fish body weight $(\mathrm{g}) /$ Protein fed $\quad{ }^{6}$ Net protein utilization= [protein gain/protein fed] $X 100$

${ }^{7}$ Percentage survival $=\{$ (total number of fish- mortality $) /$ total number of fish $]$ X 100

Ini. : Initial Fin. : Final

\section{Survival, growth performance and nutrient utilization}

Growth performance and nutrient utilization by Clarias gariepinus fed varying levels of cooked sunflower meal based experimental diets are expressed in Table 4. Percentage survival was very high $(>80 \%)$ across all dietary treatment groups and no significant difference $(p>0.05)$ was recorded in percentage survival of all the fish fed the dietary treatment except the fish fed CSF145. The control diets trated group had the best growth performance. However, the mean weight gain, specific growth rate, \% weight gain, and feed intake were statistically similar $(p>0.05)$ among the fish fed control diet and diets CSF115, CSF130, CSF215 and CSF230.

\section{Faecal sample proximate composition}

The differently fed Clarias gariepinus faecal samples' proximate compositions are presented in Table 5. A reduced nutrient contents of the faecal samples tested was observed when compared with that of the feed. The protein content of the faecal samples of fish fed diet CTR, CSF115, CSF130, CSF230, CSF315 and CSF330 were statistically similar $(p>0.05)$. No significant variation $(p>0.05)$ was observed in the crude lipid content of the faecal samples of fish fed diet CTR and that of fish fed other test diets except CSF245. The crude fibre content of the faecal output of fish fed diet CTR and fish fed other test diets except diets CSF130 CSF230 and CSF315 were statistically indifferent $(p>0.05)$.
The faecal AIA of the differently fed fish did not significantly vary $(P>0.05)$ except that of the fish fed CSF245 and CSF345. Similarly, no statistical variation $(P>0.05)$ was observed in the energy value of the faecal samples of fish fed all the dietary treatments.

\section{Apparent nutrient digestibility coefficients in each diet}

The apparent nutrient digestibility coefficient of cooked sunflower-meal based diets fed to Clarias gariepinus fingerlings is given in Table 6. Significant variations $(p<0.05)$ was observed in the nutrient digestibility's values of fish fed various dietary treatments. However, no significant difference ( $p>0.05$ ) was recorded in the AOMD of control diet fed group and test diets fed groups except that of the fish fed CSF245 and CSF345. Similarly, there was no significant variations $(p>0.05)$ in the APD of control diet fed fishand the fish fed other test diets except those fed diets CSF145, CSF245 and CSF345. Same trend of results as recorded for APD was observed in the ALD of the fish fed dietary treatments except that significant variation $(p<0.05)$ was recorded between the fish fed control diets and the fish fed CSF245, CSF330, and CSF345 diets. The AED value of the fish fed control diets were not significantly different $(p>0.05)$ from the fish fed CSF115, CSF130, CSF215 and CSF230 diets. So also, no significant difference $(p>0.05)$ was recorded in the AED values of the fish fed diets CSF145, CSF315, and CSF330. 
Fish fed control diets were not significantly different $(p>0.05)$ from the fish fed the test diets except the fish groups fed diets CSF245, CSF330, and CSF345. Apparent ash digestibility and apparent carbohydrate digestibility coefficient in all fish fed the test diets did not significantly vary $(p>0.05)$ from control except that of the CSF345.

\section{Hematological profile}

The hematological parameters of Clarias gariepinus fed differently cooked sunflower meal-based diets replacing soybean meal is presented in Table 7. There existed significant variations $(p<0.05)$ in the haemoglobin content of the fish fed various dietary treatment. However, was no significant variations $(p>0.05)$ in the haemoglobin content of fish fed control diets and test diets CSF315, CSF115, CSF215, CSF130. Similar pattern as observed above was also recorded for the PCV of the fish fed different dietary treatment except that there was significant difference $(p<0.05)$ between the control diets and diet CSF130. There was no significant difference in the white blood cell counts of fish group fed the control diet and those fed test diets; CSF115, CSF130, CSF145, CSF215, CSF230, CSF315, and CSF330. RBC decreases with increase in levels of inclusion of differently cooked sunflower. No significant variation $(p>0.05)$ existed in the MCHC of fish fed differently cooked sunflower meal-based diets and control diets except in fish fed test diets CSF345. The MCV follows the same pattern as recorded for MCHC except that fish fed diets CSF245 and CSF345 showed significant variation $(p<0.05)$ in MCV from other dietary treatments. The $\mathrm{MCH}$ of fish fed the different dietary treatments were statistically similar $(p>0.05)$. The trend of results of the ESR of fish fed differently cooked sunflower meal-based diets were similar to the pattern of results of the $\mathrm{RBC}$ recorded above

\section{Histopathology}

Different dietary treatments exhibit different changes in the liver of Clarias gariepinus. Diffuse hepatic vacuolation was recorded in control diet. Other test diets exhibit diffuse to severe fatty infiltration of hepatocytes with diffuse to severe, diffuse vacuolar degeneration of hepatocytes. Severe fatty infiltration of hepatocytes was recorded in fish fed CSF115, CSF215,230 and CSF345. Severe hepatic vacuolation were recorded in fish fed CSF130,145, CSF245, CSF315 and CSF345.

Table 5. Proximate composition ( $\mathrm{g} / 100 \mathrm{~g}$ dry matter), acid insoluble ash and energy contents of faecal samples of Clarias gariepinus fed varying replacement levels of cooked samples of sunflower seedmeal-based diets

\begin{tabular}{|c|c|c|c|c|c|c|c|c|c|c|}
\hline \multirow{2}{*}{ Parameter } & \multicolumn{10}{|c|}{ Experimental Diets } \\
\hline & CTR & CSF115 & CSF130 & CSF145 & CSF215 & CSF230 & CSF245 & CSF315 & CSF330 & CSF345 \\
\hline Moisture & $10.63 \pm 0.81^{a}$ & $10.00 \pm 1.42^{\mathrm{ab}}$ & $9.62 \pm 0.26^{b}$ & $10.10 \pm 0.23 a b$ & $10.07 \pm 0.45^{\mathrm{ab}}$ & $9.87 \pm 0.39 \mathrm{ab}$ & $9.84 \pm 0.46^{\mathrm{ab}}$ & $9.99 \pm 0.60^{\mathrm{ab}}$ & $9.93 \pm 0.47 \mathrm{sb}$ & $10.06 \pm 0.38 \mathrm{ab}$ \\
\hline Crude Protein & $15.73 \pm 0.71 \mathrm{c}$ & $15.24 \pm .31^{c}$ & $16.98 \pm 1.80 \mathrm{abc}$ & $20.17 \pm 1.33^{a b}$ & $20.53 \pm 1.04^{a}$ & $16.21 \pm 3.79 b c$ & $16.90 \pm 1.83 \mathrm{abc}$ & $15.51 \pm 2.28 c$ & $16.09 \pm 3.66^{b c}$ & $16.84 \pm 1.02^{\mathrm{abc}}$ \\
\hline Crude Lipid & $6.15 \pm 0.10^{b}$ & $6.18 \pm 0.69 \mathrm{~b}$ & $6.89 \pm 0.76^{\mathrm{ab}}$ & $6.77 \pm 1.09 \mathrm{ab}$ & $6.20 \pm 0.31 \mathrm{~b}$ & $7.19 \pm 0.99 \mathrm{ab}$ & $7.91 \pm 0.87^{a}$ & $5.94 \pm 0.74 b$ & $6.72 \pm 0.65^{\mathrm{ab}}$ & $6.50 \pm 0.31^{b}$ \\
\hline Ash & $9.65 \pm 0.41^{b}$ & $10.07 \pm 1.21^{b}$ & $10.44 \pm .51^{b}$ & $10.82 \pm 2.43^{b}$ & $10.62 \pm 0.56^{b}$ & $10.99 \pm .23^{b}$ & $11.37 \pm 1.71^{b}$ & $12.26 \pm 2.05^{b}$ & $12.43 \pm 2.86^{b}$ & $15.48 \pm 1.81^{a}$ \\
\hline Crude fibre & $11.98 \pm 0.62^{\mathrm{ab}}$ & $11.35 \pm 1.35^{\mathrm{ab}}$ & $12.44 \pm 1.20 \mathrm{a}$ & $11.17 \pm 0.27 \mathrm{ab}$ & $11.11 \pm 1.29 \mathrm{ab}$ & $12.77 \pm 1.08^{a}$ & $11.92 \pm 0.99 \mathrm{ab}$ & $12.43 \pm 0.89 a$ & $11.83 \pm 0.26 \mathrm{ab}$ & $10.31 \pm 1.15^{b}$ \\
\hline NFE & $45.86 \pm 1.30^{\mathrm{ab}}$ & $47.17 \pm 1.83^{a}$ & $43.63 \pm 3.45^{\mathrm{abc}}$ & $40.97 \pm 0.48 c$ & $41.46 \pm 1.29 c$ & $42.97 \pm 3.54 \mathrm{bc}$ & $42.07 \pm 0.48 \mathrm{bc}$ & $43.87 \pm 3.21 \mathrm{abc}$ & $43.00 \pm 1.13^{b c}$ & $40.80 \pm 0.53 c$ \\
\hline AIA & $3.29 \pm 0.38 \mathrm{ab}$ & $3.34 \pm 0.40^{\mathrm{ab}}$ & $3.40 \pm 0.27 \mathrm{ab}$ & $3.42 \pm 0.21 \mathrm{ab}$ & $3.44 \pm 0.43 a b$ & $3.38 \pm 0.05^{a b}$ & $3.06 \pm 0.20 c$ & $3.64 \pm 0.09 \mathrm{a}$ & $3.35 \pm 0.40^{\mathrm{ab}}$ & $2.67 \pm 0.13^{c}$ \\
\hline Energy (kcal/100g) & $334.52 \pm 4.12$ & $337.44 \pm 3.29$ & $339.49 \pm 2.36$ & $345.19 \pm 19.59$ & $343.92 \pm 6.70$ & $335.29 \pm 15.24$ & $342.23 \pm 5.41$ & $323.16 \pm 14.14$ & $330.26 \pm 21.93$ & $323.32 \pm 3.30$ \\
\hline
\end{tabular}

Row means with different superscripts are significantly different $(p<0.05)$

NFE: Nitrogen free Extract AIA: Acid insoluble Ash

Table 6. Apparent digestibility coefficient of nutrients of cooked sunflower meal-based diets fed to Clarias gariepinus

\begin{tabular}{|c|c|c|c|c|c|c|c|c|c|c|}
\hline \multirow{2}{*}{ Parameters } & \multicolumn{10}{|c|}{ Experimental Diets } \\
\hline & CTR & CSF115 & CSF130 & CSF145 & CSF215 & CSF230 & CSF245 & CSF315 & CSF330 & CSF345 \\
\hline AOMD & $76.99 \pm 1.69 \mathrm{ab}$ & $75.85 \pm 0.53^{\mathrm{ab}}$ & $77.19 \pm 1.03^{a}$ & $77.09 \pm 0.27 \mathrm{a}$ & $77.25 \pm 1.01^{a}$ & $77.38 \pm 0.69 \mathrm{a}$ & $74.70 \pm 0.49 b$ & $77.47 \pm 1.31$ & $75.31 \pm 0.99 \mathrm{ab}$ & $70.26 \pm 1.11 c$ \\
\hline APD & $91.01 \pm 0.42^{\mathrm{a}}$ & $90.92 \pm 0.36^{a}$ & $90.41 \pm 0.72^{\mathrm{ab}}$ & $88.53 \pm 0.62^{b c}$ & $88.37 \pm 1.00^{b c}$ & $90.92 \pm 1.98 \mathrm{a}$ & $89.39 \pm 1.11 a b c$ & $91.36 \pm 0.82^{a}$ & $90.19 \pm 2.00^{a b}$ & $87.58 \pm 0.52^{c}$ \\
\hline ALD & $88.36 \pm 0.92^{\mathrm{ab}}$ & $87.76 \pm 1.32^{a b}$ & $87.08 \pm 0.79 \mathrm{ab}$ & $87.24 \pm 1.97 \mathrm{ab}$ & $88.38 \pm 0.99 \mathrm{ab}$ & $86.59 \pm 1.49 \mathrm{ab}$ & $83.56 \pm 2.05 c$ & $89.05 \pm 0.82^{a}$ & $86.39 \pm 0.79 b$ & $84.04 \pm 1.40 c$ \\
\hline AED & $82.19 \pm 1.23^{a b}$ & $81.24 \pm 0.77^{a b}$ & $82.14 \pm 0.67^{a b}$ & $81.48 \pm 0.68^{b c}$ & $81.97 \pm 0.87 \mathrm{ab}$ & $82.51 \pm 0.46^{\mathrm{ab}}$ & $80.09 \pm 0.56^{c}$ & $83.29 \pm 0.63^{a}$ & $81.33 \pm 0.67 \mathrm{ab}$ & $77.92 \pm 0.70^{\mathrm{d}}$ \\
\hline AAD & $77.13 \pm 2.29^{a}$ & $74.76 \pm 5.74^{a}$ & $75.42 \pm 1.71^{a}$ & $74.58 \pm 6.13^{a}$ & $75.15 \pm 0.96^{a}$ & $74.39 \pm 0.13^{a}$ & $69.91 \pm 5.09 \mathrm{a}$ & $70.98 \pm 6.00^{a}$ & $67.09 \pm 8.45^{\mathrm{a}}$ & $50.54 \pm 7.59 b$ \\
\hline AFD & $53.19 \pm 1.46^{\mathrm{ab}}$ & $53.48 \pm 0.43^{\mathrm{ab}}$ & $52.83 \pm 3.16 \mathrm{abc}$ & $53.89 \pm 5.58^{\mathrm{ab}}$ & $56.71 \pm 6.60 \mathrm{a}$ & $51.68 \pm 1.88 \mathrm{abc}$ & $48.49 \pm 0.74 b c$ & $50.97 \pm 0.69 \mathrm{abc}$ & $49.25 \pm 1.33^{b c}$ & $47.14 \pm 1.24 c$ \\
\hline$A C D$ & $52.68 \pm 0.59 \mathrm{abc}$ & $49.75 \pm 7.16^{b c}$ & $55.84 \pm 5.16 \mathrm{abc}$ & $54.95 \pm 5.08 \mathrm{abc}$ & $58.63 \pm 0.33^{a}$ & $56.81 \pm 6.32^{\mathrm{ab}}$ & $53.43 \pm 0.62^{\mathrm{abc}}$ & $56.85 \pm 5.17 \mathrm{ab}$ & $54.11 \pm 3.45^{\mathrm{abc}}$ & $47.51 \pm 1.11 \mathrm{c}$ \\
\hline
\end{tabular}

Row means with different superscripts are significantly different $(p<0.05)$

AOMD Apparent Organic Matter Digestibility

APD Apparent Protein Digestibility

ALD Apparent Lipid Digestibility

AED Apparent Energy Digestibility

AAD Apparent Ash Digestibility

AF D Apparent Fibre Digestibility

ACD Apparent Carbohydrate Digestibility 
Jimoh, Ege Journal of Fisheries and Aquatic Sciences, 37(4), 343-351 (2020)

Table 7. Hematological profile of blood of Clarias gariepinus fed cooked sunflower meal-based diets

\begin{tabular}{|c|c|c|c|c|c|c|c|c|c|c|}
\hline & \multicolumn{10}{|c|}{ Experimental Diets } \\
\hline & CTR & CSF115 & CSF130 & CSF145 & CSF215 & CSF230 & CSF245 & CSF315 & CSF330 & CSF345 \\
\hline $\mathrm{Hb}$ & $10.19 \pm 0.06^{a}$ & $10.10 \pm 0.12^{\mathrm{a}}$ & $9.86 \pm 0.18^{a b}$ & $9.15 \pm 0.23 c$ & $10.08 \pm 0.07^{a}$ & $9.65 \pm 0.15^{b}$ & $8.79 \pm 0.01^{d}$ & $10.20 \pm 0.18^{a}$ & $9.62 \pm 0.13^{b}$ & $8.69 \pm 0.22^{d}$ \\
\hline PCV & $30.33 \pm 0.13^{\mathrm{ab}}$ & $30.36 \pm 0.40^{\mathrm{ab}}$ & $29.37 \pm 0.39 b c$ & $27.14 \pm 0.84^{d}$ & $30.44 \pm 0.21 \mathrm{ab}$ & $29.57 \pm 0.30 \mathrm{abc}$ & $27.03 \pm 0.65^{d}$ & $30.74 \pm 0.16^{a}$ & $28.81 \pm 0.82^{c}$ & $27.01 \pm 0.32^{d}$ \\
\hline WBC ( & $6.50 \pm 0.142^{\mathrm{abc}}$ & $6.59 \pm 0.12^{\mathrm{abc}}$ & $6.43 \pm 0.04 \mathrm{bc}$ & $6.65 \pm 0.07 \mathrm{abc}$ & $6.50 \pm 0.14 \mathrm{abc}$ & $6.40 \pm 0.21 \mathrm{bc}$ & $6.68 \pm 0.04 \mathrm{abc}$ & $6.45 \pm 0.14 \mathrm{bc}$ & $6.378 \pm 0.04 c$ & $6.74 \pm 0.05^{\mathrm{a}}$ \\
\hline RBC & $3.31 \pm 0.50^{\mathrm{ab}}$ & $3.35 \pm 0.04 a$ & $3.23 \pm 0.08 \mathrm{abc}$ & $2.93 \pm 0.07^{d}$ & $3.34 \pm 0.04 a$ & $3.19 \pm 0.06^{b c}$ & $2.87 \pm 0.11^{d}$ & $3.37 \pm 0.06^{a}$ & $3.12 \pm 0.01 c$ & $2.81 \pm 0.02^{\mathrm{d}}$ \\
\hline MCHC & $33.58 \pm 0.35^{\mathrm{a}}$ & $33.25 \pm 0.04 \mathrm{ab}$ & $33.56 \pm 0.16^{a}$ & $33.70 \pm 0.19 \mathrm{a}$ & $33.12 \pm 0.01 \mathrm{ab}$ & $32.62 \pm 0.18^{\mathrm{ab}}$ & $32.51 \pm 0.81 \mathrm{ab}$ & $33.18 \pm 0.42^{\mathrm{ab}}$ & $33.42 \pm 1.39 \mathrm{ab}$ & $32.15 \pm 0.43^{b}$ \\
\hline MCV & $91.78 \pm 0.99 c$ & $90.63 \pm 0.04 c$ & $90.93 \pm 1.19 c$ & $92.60 \pm 0.64 \mathrm{bc}$ & $91.14 \pm 0.52^{c}$ & $92.71 \pm 0.71 \mathrm{bc}$ & $94.37 \pm 1.22^{\mathrm{ab}}$ & $91.23 \pm 1.07 c$ & $92.34 \pm 2.21 \mathrm{bc}$ & $96.28 \pm 0.40^{a}$ \\
\hline $\mathrm{MCH}$ & $30.82 \pm 0.65^{\mathrm{a}}$ & $30.14 \pm 0.02^{\mathrm{a}}$ & $30.51 \pm 0.26^{a}$ & $31.21 \pm 0.04^{a}$ & $30.18 \pm 0.17 \mathrm{a}$ & $30.24 \pm 0.07 \mathrm{a}$ & $30.69 \pm 1.17 \mathrm{a}$ & $30.27 \pm 0.04 a$ & $30.84 \pm 0.55^{\mathrm{a}}$ & $30.96 \pm 0.55$ \\
\hline ESR & $3.67 \pm 0.02^{\mathrm{a}}$ & $3.63 \pm 0.04 \mathrm{a}$ & $3.55 \pm 0.06^{\mathrm{ab}}$ & $3.29 \pm 0.09 c$ & $3.63 \pm 0.02^{\mathrm{a}}$ & $3.47 \pm 0.06^{b}$ & $3.16 \pm 0.04^{d}$ & $3.67 \pm 0.07 a$ & $3.46 \pm 0.04 \mathrm{~b}$ & $3.13 \pm 0.08^{d}$ \\
\hline
\end{tabular}

Row means with different superscripts are significantly different $(p<0.05)$.

$\mathrm{Hb}$ : Haemoglobin content (gm/100ml) PCV: Packed Cell Volume (\%) WBC: White Blood Cell Count (104mm $\left.{ }^{3}\right)$

RBC: Red Blood Cell Count $\left(10^{6} \mathrm{~mm}^{3}\right) \quad$ MCHC: Mean Corpuscular Haemoglobin Concentration (\%)

MCV: Mean Corpuscular Volume $\left(\mathrm{u}^{3}\right) \quad \mathrm{MCH}$ : Mean Corpuscular Haemoglobin (pg)

ESR: Erythrocyte Sedimentation Rate $(\mathrm{mm} / \mathrm{hr})$

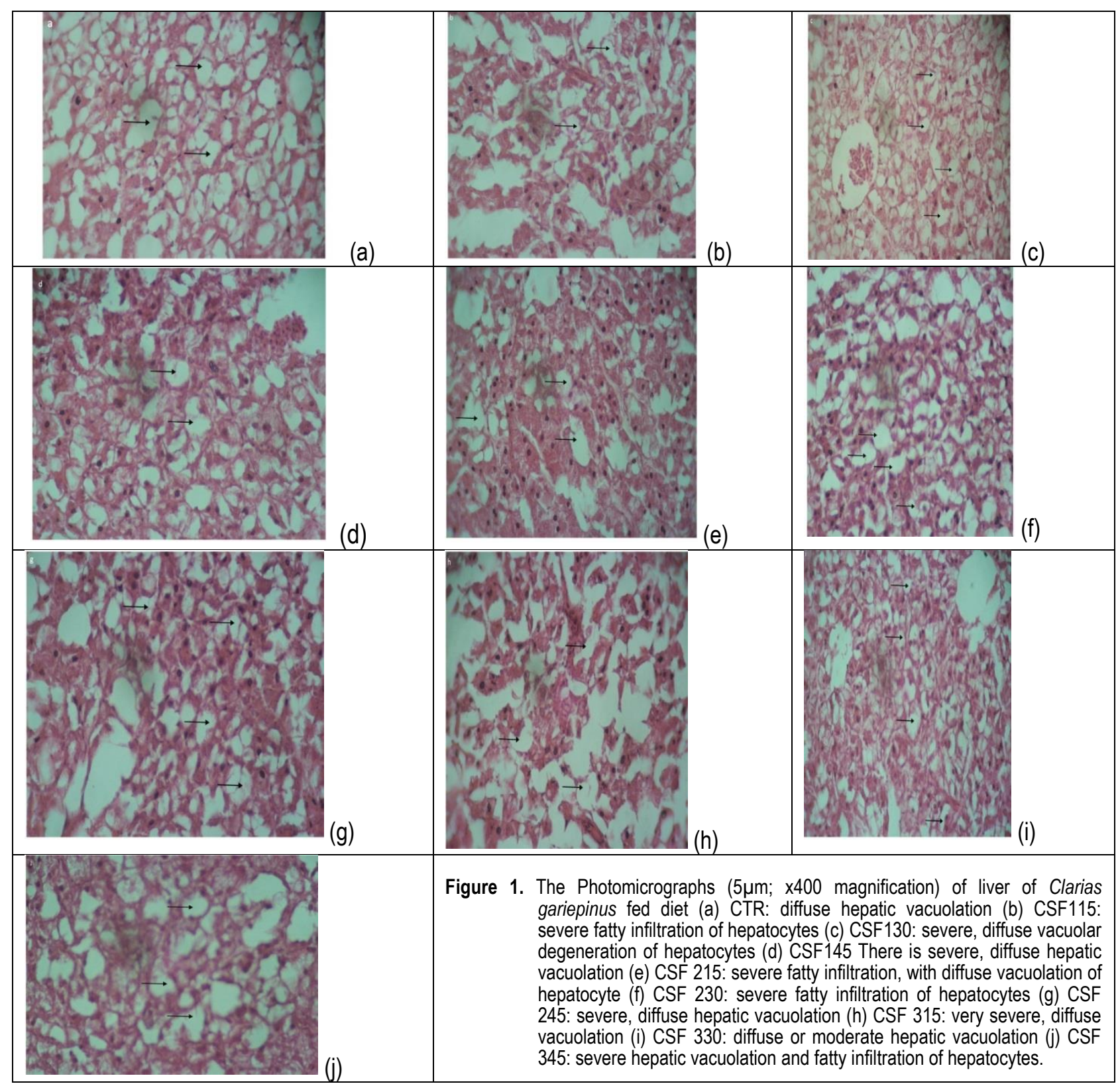




\section{DISCUSSION}

The best growth performance was recorded in fish fed the soybean-based control diets which was not statistically different from the fish exposed to diets CSF115, CSF130, CSF215 and CSF230. Lower cooking time and inclusion level of sunflower seed meal had a comparable performance with control diets. Our result is in consonance with the observation of Köprücü and Sertel (2012) who also reported the superior growth performance by carp, Ctenopharyngodon Idella, fed soybean based control diet over that of fish fed sunflower based diets. The nutrient profile of soybean seed meal is superior to that other plant protein sources (Storebakken, 2000). The reduction in growth performance by Clarias gariepinus at higher inclusion level might not be unconnected to higher crude fibre content of sunflower seedmeal. Higher content of crude fibre has been reported to limit its use in aquaculture diets (Hertrampf and Piedad-Pascual, 2012). Other plausible reason could be the presence of chlorogenic acid and caffeic acid; the phenolic compounds that have capacity to reduce protein solubility (González-Pérez and Vereijken, 2007). Crude fibre and these phenolic compounds are present at lower inclusion level but their presence could still be contained by the physiological mechanisms of fish. There is tolerable level of these compounds in fish within which the physiological mechanism of fish will not be impaired (Francis et al., 2001). Other studies that establish lower growth performance at higher inclusion of sunflower seedmeal are Jackson et al. (1982); Tacon et al. (1984); Stickney et al. (1996); Sintayehu et al. (1996); Olvera-Novoa et al. (2002).

Carcass crude protein and carcass crude lipid followed the same trend as observed with growth performance. They reduced with increase in cooking time and inclusion level. No significant variation was recorded in the carcass protein of fish fed CTR, CSF115, CSF130, CSF215, CSF315. This result is in consonance with the finding of Hassaan et al. (2015) who reported decrease in carcass protein with increase inclusion level of fermented soybean meal. Our results are in tandem with the observation of Saha and Ghosh (2013) for rohu, Labeo rohita fed Jatropha curcas seedmeal and Hassaan et al. (2017) for fermented, de-oiled Jatropha curcas fed to Oreochromis niloticus. The reduction in carcass lipid content at higher inclusion level observed in this study could be traceable to phenolic compounds, chlorogenic acid, an anti-oxidant that has capacity to reduce deposition of lipid in the carcass (Sun et al., 2017). Similar observation was made by Hassaan et al. (2017). The reduction in lipid level with increasing inclusion level recorded in this study is in consonance with the observation of Zhou et al. (2011). Jimoh et al. (2019) reported similar trends of results when hybrid lemon fin barb (Barbonymus gonionotus $q \times$ Hypsibarbus wetmorei $\precsim$ ) was fed diets containing selected leaf meals of dietary high fibre.

The non-significant difference recorded in the apparent protein and lipid digestibility of control diet fed fish group and other test diets' fed groups except those fed diets CSF145, CSF245 and CSF345 gave a better picture of the growth performance trend, the higher the amount of input to metabolism as a result of digestibility, the higher the anabolism activity for protein accretion (Lim et al., 2004). The lower digestibility coefficient recorded for protein and lipid in this study at higher inclusion level irrespective of the processing time employed was in tandem with the report of Hassaan et al. (2017). At higher inclusion level, the nondigestible cellulose content increases, the anti-nutrient component increases making the amino acids in the diet become imbalanced (Eusebio et al., 2004; Zhou et al., 2011) which explains why the digestibility coefficient reduced when compared with control.

No significant differences were recorded in the haemoglobin content, RBC and PCV contents control diet fed group and fish fed test diets; CSF315, CSF115, CSF215, CSF130. Similarly, there was no significant difference in the white blood cell counts of fish group fed the control diet and those fed test diets except CSF345. These are primary indicator of fish physiology; good for knowing the health status of fish (Bahmani et al., 2001). Diet composition can change blood profile (Feist and Longshaw, 2000). The trend of results obtained in this study agrees with Aderolu et al. (2015) who fed degraded rice husk to Nile tilapia. Blom et al. (2001) and Rinchard et al. (2003) also reported a decrease in primary haematological parameters with inclusion of plant protein sources. Possible reason for the trend of haematological parameters recorded in this study might be attributed to the stress created as a result of anti-nutrient, higher fibre content and quality of amino acid content of the diet (Zhou et al., 2011). Although contrast is the report of Jimoh et al. (2015a) who fed Citrullus lanatus to Oreochromis niloticus that higher profile of haematological parameters were recorded.

Diffuse to severe fatty infiltration of hepatocytes with diffuse to severe vacuolar degeneration of hepatocytes. Severe hepatic vacuolation were recorded in fish fed CSF130,145, CSF245, CSF315 and CSF345. Jimoh et al. (2015b) reported similar trends of results when Citrullus lanatus was fed to Nile tilapia (Oreochromis niloticus). The pathological condition recorded in this study might be attributable to the presence of anti-nutrients in the feedstuff. Gatta et al. (2011) gave plausible reason to the high vacuolation of the hepatocytes as dietary lipid induced. The presence of high vacuolation of the liver was reported also reported by Valente et al. (2011). Liver is susceptible to damage as a result of its metabolic function of detoxifying xenobiotic compounds. (Nero et al., 2006).

\section{CONCLUSION}

The replacement level of soybean meal by sunflower seedmeal that supports optimum performance by Clarias gariepinus appear from this study to be up to $30 \%$ for 10 and 20 minutes cooked sunflower seedmeal or $15 \%$ for 30 minutes cooked sunflower seedmeal. 


\section{REFERENCES}

Adeparusi, E.O. \& Jimoh, W.A. (2002). Digestibility coefficients of raw and processed lima bean diet for Nile tilapia, Oreochromis niloticus. Journal of Applied Aquaculture, 12(3), 89-98. DOI: 10.1300/J028v12n03_09

Aderolu, A.Z., Jimoh, W. A., Lawal, M.O. \& Aarode, O.O. (2015). Effects of Pleurotus tuberegium degraded rice husk on growth, nutrient utilisation, haematology and biochemical parameters In Nile Tilapia. Production, Agriculture and Technology, 11(1), 32-43.

Akintayo, I., Obasa, S., Alegbeleye, W., \& Bangbose, A. (2008). Evaluation of toasted sunflower (Helianthus annus) seed meal in the diets of African catfish (Clarias gariepinus) fingerlings. Livestock Research for Rural Development, 20(10), 28-46.

Alarcón, F.J., Moyano, F.J. \& Díaz, M. (1999). Effect of inhibitors present in protein sources on digestive proteases of juvenile sea bream (Sparus aurata). Aquatic Living Resources, 12(4), 233-238. DOI:10.1016/S0990-7440(00)86633-4

Azaza, M., Wassim, K., Mensi, F., Abdelmouleh, A., Brini, B. \& Kraïem, M. (2009). Evaluation of faba beans (Vicia faba L. var. minuta) as a replacement for soybean meal in practical diets of juvenile Nile tilapia Oreochromis niloticus. Aquaculture, 287(1-2), 174-179. DOI:10.1016/j.aquaculture.2008.10.007

Bahmani, M., Kazemi, R. \& Donskaya, P. (2001). A comparative study of some hematological features in young reared sturgeons (Acipenser persicus and Huso huso). Fish Physiology and Biochemistry, 24(2), 135140. DOI:10.1023/A:1011911019155

Bancroft, J.D. \& Cook, H.C. (1994). Manual of histological techniques and their diagnostic application: Churchill Livingstone.

Blom, J., Lee, K.-J., Rinchard, J., Dabrowski, K., \& Ottobre, J. (2001). Reproductive efficiency and maternal-offspring transfer of gossypol in rainbow trout (Oncorhynchus mykiss) fed diets containing cottonseed meal. Journal of animal science, 79(6), 1533-1539. DOI: $10.2527 / 2001.7961533 x$

Eusebio, P.S., Coloso, R.M. \& Mamauag, R.E. (2004). Apparent digestibility of selected ingredients in diets for juvenile grouper, Epinephelus coioides (Hamilton). Aquaculture Research, 35(13), 1261-1269. DOI:10.1111/j.1365-2109.2004.01148.x

Fagbenro, O., Adeparusi, E. \& Jimoh, W. (2010). Nutritional evaluation of sunflower and sesame seed meal in Clarias gariepinus: An assessment by growth performance and nutrient utilization. African Journal of Agricultural Research, 5(22), 3096-3101.

Feist, S. \& Longshaw, M. (2000). Myxosporidiosis of fish and the bryozoan link with proliferative kidney disease (PKD) of salmonids. Fish Vet. J, 5, 37-46.

Francis, G., Makkar, H.P. \& Becker, K. (2001). Antinutritional factors present in plant-derived alternate fish feed ingredients and their effects in fish. Aquaculture, 199(3-4), 197-227. DOI:10.1016/S0044-8486(01)00526-9

Garcia-Gallego, M., Akharbach, H. \& De la Higuera, M. (1998). Use of protein sources alternative to fish meal in diets with amino acids supplementation for the European eel (Anguilla anguilla). Animal science, 66(1), 285-292. DOI:10.1017/S1357729800009073

Gatta, P. P., Parma, L., Guarniero, I., Mandrioli, L., Sirri, R., Fontanillas, R. \& Bonaldo, A. (2011). Growth, feed utilization and liver histology of juvenile common sole (Solea solea L.) fed isoenergetic diets with increasing protein levels. Aquaculture Research, 42(3), 313-321. DOI:10.1111/j.1365-2109.2010.02622.x

Gaylord, T., Rawles, S. \& Gatlin III, D. (2004). Amino acid availability from animal, blended, and plant feedstuffs for hybrid striped bass (Morone chrysops× M. saxatilis). Aquaculture Nutrition, 10(5), 345-352. DOI:10.1111/j.1365-2095.2004.00310.x

Gill, N., Higgs, D. A., Skura, B. J., Rowshandeli, M., Dosanjh, B. S., Mann, J. \& Gannam, A. L. (2006). Nutritive value of partially dehulled and extruded sunflower meal for post-smolt Atlantic salmon (Salmo salar L.) in sea water. Aquaculture Research, 37(13), 1348-1359. DOI:10.1111/j.1365-2109.2006.01567.x
Gohl, B. (1991). Tropical Feeds, FAO: Oxford Computer Journals LTD, Version.

González-Pérez, S. \& Vereijken, J. M. (2007). Sunflower proteins: overview of their physicochemical, structural and functional properties. Journal of the Science of Food and Agriculture, 87(12), 2173-2191. DOI:10.1002/jsfa.2971

Hassaan, M., Goda, A.S. \& Kumar, V. (2017). Evaluation of nutritive value of fermented de-oiled physic nut, Jatropha curcas, seed meal for Nile tilapia Oreochromis niloticus fingerlings. Aquaculture Nutrition, 23(3), 571-584. DOI:10.1111/anu.12424

Hassaan, M.S., Soltan, M.A. \& Abdel-Moez, A.M. (2015). Nutritive value of soybean meal after solid state fermentation with Saccharomyces cerevisiae for Nile tilapia, Oreochromis niloticus. Animal Feed Science and Technology, 201, 89-98. DOI:10.1016/j.anifeedsci.2015.01.007

Hassaan, M.S., Soltan, M.A., Mohammady, E.Y., Elashry, M.A., El-Haroun, E. R. \& Davies, S.J. (2018). Growth and physiological responses of Nile tilapia, Oreochromis niloticus fed dietary fermented sunflower meal inoculated with Saccharomyces cerevisiae and Bacillus subtilis. Aquaculture, 495, 592-601. DOI:10.1016/j.aquaculture.2018.06.018

Hertrampf, J.W. \& Piedad-Pascual, F. (2012). Handbook on ingredients for aquaculture feeds: Springer Science \& Business Media.

Jackson, A., Capper, B. \& Matty, A. (1982). Evaluation of some plant proteins in complete diets for the tilapia Sarotherodon mossambicus. Aquaculture, 27(2), 97-109. DOI:10.1016/0044-8486(82)90129-6

Jimoh, Aderolu, A. Z., Ayeloja, \& Shodamola. (2013a). Replacement Value of Soybean Meal with Luffa cylindrical in Diet of Clarias gariepinus Fingerlings. IJAAAR International Journal of Applied Agricultural and Apicultural Research, 9(2), 98-105.

Jimoh, W.A. \& Aroyehun, H.T. (2011). Evaluation of cooked and mechanically defatted sesame (Sesamum indicum) seed meal as a replacer for soybean meal in the diet of African catfish (Clarias gariepinus). Turkish Journal of Fisheries and Aquatic Sciences, 11, 185190. DOI:10.4194/trjfas.2011.0202

Jimoh, W.A., Awodele, A.O., Okemakin, F.Y., Ayeloja, A.A., Abdusalami, S. A. \& F.A., A. (2014a). Apparent digestibility experiment with tilapia fed diets containing Citrullus lanatus seedmeal. Annals of West University of Timişoara, ser. Biology, 18(2), 159-168.

Jimoh, W.A., Ayeloja, A.A., Ajasin, F.O., Okemakin, F.Y., Abdusalami, S.A. \& Adekunle, O.F. (2015a). Some haematological and biochemical profile of blood of Nile tilapia (Oreochromis niloticus) fed on diets containing watermelon (Citrullus lanatus) seedmeal. Bayero Journal of Pure and Applied Sciences, 8(1), 109-114. DOI:10.4314/bajopas.v8i1.19

Jimoh, W.A., Fagbenro, O.A. \& Adeparusi, E. O. (2014b). Response of African catfish, Clarias gariepinus (Burchell 1822), fingerlings fed diets containing differently timed wet-heat-treated sesame (Sesamum indicum) seedmeal. Agricultural Sciences, 5(October), 1159-1171. DOI:10.4236/as.2014.512126

Jimoh, W.A., Fagbenro, O.A. \& Adeparusi. E.O. (2010). Digestibility coefficients of processed jackbean meal Cannavalia ensiformis (L.) DC for Nile tilapia, Oreochromis niloticus (Linnaeus, 1758) diets. International Journal of Fisheries and Aquaculture, 2(4), 102-107.

Jimoh, W.A., Kamarudin, M.S., Sulaiman, M.A. \& Dauda, A.B. (2019). Assessment of prebiotic potentials in selected leaf meals of high dietary fibre on growth performance, body composition, nutrient utilization and amylase activities of a tropical commercial carp fingerlings. Aquaculture Research (00), 1-11. DOI:10.1111/are.14298

Jimoh, W. A., Olawepo, K.D., Ayeloja, A.A., Ashraf, A.O. \& Shodamola, M. O. (2013b). Evaluation of water melon seedmeal (Citrullus lanatus) as a replacer for soybean seedmeal in the diet of African catfish (Clarias gariepinus). Paper presented at the 47th Annual Conference of Agricultural Society of Nigeria (ASN) held between 4th and 8th November, 2013, Federal College of Animal Health and Production Technology, Moor Plantation, Ibadan, Nigeria.

Jimoh, W.A., Shittu, M.O., Ayeloja, A.A., Okemakin, F.Y., Abdulsalami, S.A., Adekunle, O.F. \& Banjoko, O.J. (2015b). Histological changes in the liver of Nile tilapia (Oreochromis niloticus) fed diets containing watermelon (Citrullus lanatus) at varying replacement levels. Journal of Sustainable Technology, 6( 1), 85-92. 
Köprücü, K. \& Sertel, E. (2012). The effects of less-expensive plant protein sources replaced with soybean meal in the juvenile diet of grass carp (Ctenopharyngodon idella): growth, nutrient utilization and body composition. Aquaculture International, 20(3), 399-412. DOI:10.1007/s10499-011-9471-7

Kumar, V., Makkar, H.P., Amselgruber, W. \& Becker, K. (2010). Physiological, haematological and histopathological responses in common carp (Cyprinus carpio L.) fingerlings fed with differently detoxified Jatropha curcas kernel meal. Food and Chemical Toxicology, 48(8-9), 2063-2072. DOI:10.1016/j.fct.2010.05.007

Lim, S., Choi, S., Wang, X., Kim, K., Shin, I., Min, T. \& Bai, S. (2004). Effects of dehulled soybean meal as a fish meal replacer in diets for fingerling and growing Korean rockfish Sebastes schlegeli. Aquaculture, 231(1-4), 457-468. DOI:10.1016/j. aquaculture.2003.09.008

Lozano, N.B.S., Vidal, A.T., Martínez-Llorens, S., Mérida, S.N., Blanco, J.E., López, A.M., Torres, M.P. \& Cerdá, M.J. (2007). Growth and economic profit of gilthead sea bream (Sparus aurata, L.) fed sunflower meal. Aquaculture, 272(1-4), 528-534. DOI:10.1016/j.aquaculture.2007.07.221

Nero, V., Farwell, A., Lister, A., Van Der Kraak, G., Lee, L., Van Meer, T., MacKinnon, M. \& Dixon, D. (2006). Gill and liver histopathological changes in yellow perch (Perca flavescens) and goldfish (Carassius auratus) exposed to oil sands process-affected water. Ecotoxicology and environmental safety, 63(3), 365-377. DOI:10.1016/j.ecoenv.2005.04.014

Olvera-Novoa, M.A., Olivera-Castillo, L. \& Martínez-Palacios, C.A. (2002). Sunflower seed meal as a protein source in diets for Tilapia rendall (Boulanger, 1896) fingerlings. Aquaculture Research, 33(3), 223-229. DOI:10.1046/j.1365-2109.2002.00666.x

Rinchard, J., Lee, K., Czesny, S., Ciereszko, A. \& Dabrowski, K. (2003). Effect of feeding cottonseed meal-containing diets to broodstock rainbow trout and their impact on the growth of their progenies. Aquaculture, 227(1-4), 77-87. DOI:10.1016/S0044-8486(03)00496-4

Saha, S. \& Ghosh, K. (2013). Evaluation of nutritive value of raw and fermented de-oiled physic nut, Jatropha curcas seed meal in the formulated diets for rohu, Labeo rohita (Hamilton) fingerlings. Paper presented at the Proceedings of the zoological society.

Sanz, A., Morales, A.E., de la Higuera, M. \& Gardenete, G. (1994). Sunflower meal compared with soybean meals as partial substitutes for fish meal in rainbow trout (Oncorhynchus mykiss) diets: protein and energy utilization. Aquaculture, 128(3), 287-300. DOI:10.1016/0044-8486(94)90318-2

Sintayehu, A., Mathies, E., Meyer-Burgdorff, K.H., Rosenow, H. \& Günther, K.D. (1996). Apparent digestibilities and growth experiments with tilapia (Oreochromis niloticus) fed soybean meal, cottonseed meal and sunflower seed meal. Journal of Applied Ichthyology, 12(2), 125-130. DOI:10.1111/j.1439-0426.1996.tb00075.x
Soltan, M. (2005). Potential of using raw and processed canola seed meal as an alternative fish meal protein source in diets for Nile tilapia,(Oreochromis niloticus). Egyptian J. Nutrition and Feeds, 8(1), 1111-1128.

Spackman, D.H., Stein, W.H. \& Moore, S. (1958). Automatic recording apparatus for use in chromatography of amino acids. Analytical chemistry, 30(7), 1190-1206. DOI:10.1021/ac60139a006

Stickney, R.R., Hardy, R.W., Koch, K., Harrold, R., Seawright, D. \& Massee, K.C. (1996). The effects of substituting selected oilseed protein concentrates for fish meal in rainbow trout Oncorhynchus mykiss diets. Journal of the world Aquaculture Society, 27(1), 57-63. DOI:10.1111/j.1749-7345.1996.tb00594.x

Storebakken, T. (2000). Soy products as fat and protein sources in fish feeds for intensive aquaculture. Soy in animal nutrition, 127-170.

Sun, W., Li, X., Xu, H., Chen, J., Xu, X. \& Leng, X. (2017). Effects of dietary chlorogenic acid on growth, flesh quality and serum biochemical indices of grass carp (Ctenopharyngodon idella). Aquaculture Nutrition, 23(6), 1254-1263. DOl:10.1111/anu.12500

Svobodova, Z., Pravda, D. \& Palackova, J. (1991). Unified methods of haematological examination of fish: Research Institute of fish culture and hydrobiology.

Tacon, A., Webster, J. \& Martinez, C. (1984). Use of solvent extracted sunflower seed meal in complete diets for fingerling rainbow trout (Salmo gairdneri Richardson). Aquaculture, 43(4), 381-389. DOI:10.1016/0044-8486(84)90246-1

Tacon, A. G. \& Metian, M. (2008). Global overview on the use of fish meal and fish oil in industrially compounded aquafeeds: Trends and future prospects. Aquaculture, 285(1-4), 146-158. DOI:10.1016/j.aquaculture.2008.08.015

Tacon, A.G.J. (1995). Fishmeal replacers: Review of antinutrients within oilseeds and pulses - A limiting factor for the aquafeed. (September), 19-20.

Troell, M., Naylor, R. L., Metian, M., Beveridge, M., Tyedmers, P.H., Folke, C., Arrow, K.J., Barrett, S., Crépin, A.-S. \& Ehrlich, P. R. (2014). Does aquaculture add resilience to the global food system? Proceedings of the National Academy of Sciences, 111(37), 13257-13263. DOI:10.1073/pnas.1404067111

Valente, L., Linares, F., Villanueva, J., Silva, J., Espe, M., Escórcio, C., Pires, M., Saavedra, M., Borges, P. \& Medale, F. (2011). Dietary protein source or energy levels have no major impact on growth performance, nutrient utilisation or flesh fatty acids composition of market-sized Senegalese sole. Aquaculture, 318(1-2), 128-137. DOl:10.1016/j.aquaculture.2011.05.026

Zhou, F., Song, W., Shao, Q., Peng, X., Xiao, J., Hua, Y., Owari, B. N., Zhang, T. \& Ng, W. K. (2011). Partial replacement of fish meal by fermented soybean meal in diets for black sea bream, Acanthopagrus schlegelii, juveniles. Journal of the world Aquaculture Society, 42(2), 184-197. DOI:10.1111/j.1749-7345.2011.00455.x 